ISSN : 2622-6154 (print)

\title{
FAKTOR-FAKTOR YANG MEMPENGARUHI PENGADAAN MELON DI PASAR INDUK OSOWILANGUN SURABAYA
}

\author{
Prafi Fachjurin $\mathbf{M}^{\mathbf{1}}$, Gumoyo Mumpuni Ningsih ${ }^{2}$, Ary Bakhtiar ${ }^{3}$ \\ ${ }^{1}$ Alumni Program Studi Agribisnis, Fakultas Pertanian-Peternakan, Universitas Muhammadiyah Malang \\ ${ }^{2,3}$ Dosen Program Studi Agribisnis, Fakultas Pertanian-Peternakan, Universitas Muhammadiyah \\ Malang
}

Jalan Raya Tlogomas No. 246 Malang, Jawa Timur 65144. Telp. (0341) 463513

Email korespondensi: fachjurin_may@yahoo.com

\begin{abstract}
The procurement of goods is the regulation of purchasing goods based on the market needs. The activity of supplying melons is useful to keep from damage or decay because of too long at inventory. The study purposed to determine factors affecting the procurement of melons in the market, and the procurement constraints. The accidental sampling was used in the study, while the type of data is primary. The data collection methods were observation, questionnaire, and interview. The analytical method used was multiple linear regression. The results showed that the cost of transportation and maintenance were have a significant effect on melon procurement. The constraints of melon procurement include supplyers accessed by traders in the East Java area, lighter transportation costs, controlable quality of melons, a not different prices from those of outside East Java, the risk of shipping, and price competition.
\end{abstract}

Keywords: Maintenance Costs, Melon Prices, Transportation Costs.

\section{INTISARI}

Pengadaan barang merupakan pengaturan barang masuk sesuai dengan kebutuhan pasar. Kegiatan pengadaan buah melon berguna untuk menjaga dari kerusakan atau pembusukan karena terlalu lama menjadi persediaan pasar.Tujuan penelitian untuk mengetahui faktor-faktor (harga beli melon, harga jual melon, biaya transportasi dan biaya pemeliharaan) yang mempengaruhi pengadaan melon di pasar, serta kendala pengadaan. Metode pengambilan sampel menggunakan accidental sampling, sedangkan jenis data yang digunakan adalah data primer. Metode pengumpulan data yaitu dengan observasi, kuesioner, dan wawancara dan metode analisis yang digunakan yaitu regresi linier berganda. Hasil penelitian yaitu biaya transportasi dan biaya pemeliharaan melon merupakan variabel yang berpengaruh signifikan terhadap pengadaan melon. Kendala dalam pengadaan melon antara lain supplyer yang dimiliki pedagang di area Jawa Timur, biaya transportasi yang lebih ringan, kualitas melon yang dapat dipantau, harga yang tidak berbeda jauh dengan harga di luar Jawa Timur, risiko pengiriman, dan persaingan harga.

Kata kunci: Biaya Transportasi, Harga Melon, Biaya Pemeliharaan

\section{PENDAHULUAN}

Melon merupakan usaha di sektor pertanian yang sudah lama ada di Indonesia, akan tetapi menurut Simatupang, (2004) usahatani melon adalah jenis usahatani yang relatif baru diusahakan petani Sumatera Utara. Usahatani melon adalah jenis usaha tani yang memenuhi syarat dan perlu mendapat perhatian dalam pengembangannya. Hal ini didasarkan pada kenyataan bahwa produk usahatani melon sangat digemari masyarakat baik sebagai buah segar maupun juice bahkan sebagai bahan baku industri minuman. Selain itu, harga buah melon yang relatif tinggi dibanding komoditas sejenis merupakan peluang besar untuk peningkatan pendapatan dan kesejahteraan petani melon.

Data yang diambil dari BPS (2014) menyatakan bahwa tingkat produksi buah melon di Indonesia mencapai 150.347 Ton/tahun dengan luas panen 8.185 Ha. Data tersebut menunjukan bahwa buah melon bukan merupakan komoditas yang memberikan kontribusi terbesar terhadap produksi buah nasional. Jawa timur BPS (2014) mencatat produksi buah melon mencapai 57.681 ton dengan luas lahan panen $2.757 \mathrm{Ha}$ yang berarti rata-rata per hektar dapat memproduksi 20,92 Ton/Ha. 
ISSN : 2622-6154 (print)

Buah yang memiliki masa atau waktu pembusukan apabila terlalu lama disimpan, sehingga akan sangat merugikan pihak pelaku dagang atau pasar. Dalam melakukan pengadaan melon, pedagang juga harus melihat faktor-faktor yang menjadikan pedagang harus melakukan pengadaan seperti harga melon, biaya transportasi dan biaya pemeliharaan melon serta manejemen perhitungan seberapa banyak jumlah yang akan dibeli untuk kebutuhan pasar, sehingga dapat terkontrol dengan baik dan mendapatkan profit atau keuntungan yang baik.

Berdasarkan hal tersebut maka penelitian ini menganalisis factor-faktor yang menjadikan pedagang harus melakukan pengadaan barang dan melihat kendala atau resiko pengadaan di salah satu pasar besar atau grosir di Jawa Timur yaitu Pasar Induk Osowilangun yang terletak di Jl. Tambak Osowilangun No.236. Tambak Osowilangun, Kec. Benowo, Kota Surabaya, Jawa Timur. Pengambilan tempat dilakkan secara sengaja mengingat pasar tersebut merupakan salah satu pasar grosir buah dan sayur terbesr di Jawa Timur. Pedagang buah melon dipasar ini sebenarnya merupakan pedagang pasar pindahan dari pasar Tanjungsari Surabaya. Pasar tersebut merupakan pasar grosir sayur dan buah-buahan di Surabaya, sehingga banyak pedagang sayur dan buah-buahan berkumpul disana. Pengadaan barang atau produk untuk dijual merupakan barang dari pertanian yang berada di Jawa Timur maupun luar Jawa Timur bahkan barang impor dari luar negri.

\section{METODE PENELITIAN}

Penelitian dilakukan pada bulan Agustus 2019 dengan lokasi di Pasar Induk Osowilangon Surabaya (PIOS). Metode pengambilan sampel dilakukan secara Sensus dengan cara mengambil seluruh responden pedagang melon yang berada di PIOS. Jumlah responden sebanyak 32 orang. Data primer diperoleh dengan wawancara. Metode analisis data yang digunakan analisis regresi linier berganda dengan persamaan regresi :

$$
y=a+b_{1} x_{1}+b_{2} x_{2}+b_{3} x_{3}+b_{4} x_{4}+e
$$

Dimana :

$Y=$ Pengadaan Melon

$a=$ Nilai Konstanta

$b=$ Koefisien regresi

$x_{1}=$ Harga Beli

$x_{2}=$ Harga Jual

$x_{3}=$ Biaya Transportasi

$x_{4}=$ Biaya Pemeliharaan

\section{HASIL DAN PEMBAHASAN}

\section{Karakteristik Responden}

Hasil yang diperoleh dari wawancara yang dilakukan di Pasar Induk Osowilangon Surabaya (PIOS) dengan 32 responden. Wawancara dilakukan dengan pedagang melon yang berada di Pasar Induk Osowilangon Surabaya (PIOS). Data penelitian diambil pada bulan Agustus 2019. 


\subsection{Karakteristik Responden Berdasarkan Jenis Kelamin}

Tabel 1. Distribusi Responden Berdasarkan Jenis Kelamin

\begin{tabular}{lll}
\hline Jenis Kelamin & Jumlah (orang) & Persentase (\%) \\
\hline Laki-laki & 29 & 90,6 \\
Perempuan & 3 & 9,4 \\
\hline Jumlah & 32 & 100 \\
\hline
\end{tabular}

Sumber : Data Primer Diolah, 2019

Tabel 1 menunjukan bahwa responden berjenis kelamin laki-laki adalah terbanyak yang berjumlah 29 orang $(90,6 \%)$, sedangkan sisanya merupakan responden berjenis kelamin perempuan yang berjumlah 3 orang $(9,4 \%)$. Data tersebut menunjukan bahwa mayoritas pelaku pasar merupakan berjenis kelamin laki-laki dikarenakan kegiatan pasar tersebut membutuhkan tenaga yang lebih untuk aktifitas pengangkatan melon ke konsumen.

\subsection{Karakteristik Responden Berdasarkan Usia}

Tabel 2. Distribusi Responden Berdasarkan Usia

\begin{tabular}{|c|c|c|}
\hline $\begin{array}{l}\text { Penggolongan } \\
\text { (tahun) }\end{array}$ & $\begin{array}{ll}\text { Usia } & \begin{array}{l}\text { Jumlah } \\
\text { (orang) }\end{array} \\
\end{array}$ & Persentase $(\%)$ \\
\hline 21-35 & 1 & $3,12 \%$ \\
\hline $36-50$ & 25 & $78,12 \%$ \\
\hline$>51$ & 6 & $18,75 \%$ \\
\hline Jumlah & 32 & $100 \%$ \\
\hline
\end{tabular}

Sumber : Data Primer Diolah, 2019

Table 2 menunjukan bahwa responden yang memiliki usia 21 - 35 tahun sejumlah 1 orang $(3,12 \%)$, sedangkan responden yang memiliki usia 36 - 50 tahun sejumlah 25 orang $(78,12 \%)$ dan responden yang memiliki usia $>51$ tahun sejumlah 6 orang $(18,75 \%)$. Data pada tabel 5.2 menunjukan mayoritas usia pedagang melon di Pasar Induk Osowilangun Surabaya (PIOS) berusia 36 tahun sampai 50 tahun, yang mana usia tersebut merupakan usia yang matang dalam berfikir dan menentukan keputusan, sosialisasi atau negosiasi yang baik, dapat dipercaya, memiliki nilai dan norma, partisipasi aktif sesama pedagang, struktur atau aturan yang dihormati bersama. Usia yang matang akan membantu setiap pedagang memiliki unsur-unsur tersebut. (Rismawati, 2010)

1.3 Karakterisktik Responden Berdasarkan Tanggungan Keluarga Tabel 3. Distribusi Responden Berdasarkan Tanggungan Keluarga

\begin{tabular}{|c|c|c|}
\hline $\begin{array}{ll}\text { Jumlah } & \text { Tanggungan } \\
\text { Keluarga } & \\
\end{array}$ & Frekuensi & Persentase $(\%)$ \\
\hline 1 - 3 Orang & 4 & $12.5 \%$ \\
\hline 4 - 5 Orang & 22 & $68.75 \%$ \\
\hline$>6$ Orang & 6 & $18.75 \%$ \\
\hline Jumlah & 32 & $100 \%$ \\
\hline
\end{tabular}

Sumber : Data Primer Diolah, 2019 
ISSN : 2622-6154 (print)

Tabel 3 menunjukan hasil bahwa pedagang yang memiliki jumlah tanggungan keluarga 1-3 orang sebanyak 4 orang (12,5\%), sedangkan pedagang yang memiliki $4-5$ orang sebanyak 22 orang $(68,75 \%)$, dan pedagang yang memiliki $>6$ orang jumlah tanggungan keluarga sebanyak 6 orang (18,75\%). Purwanto \& Taftazani, (2018) mengatakan bahwa Jumlah tanggungan keluarga adalah jumlah anggota keluarga yang masih menjadi tanggungan dari keluarga tersebut, baik itu saudara kandung maupun saudara bukan kandung yang tinggal dalam satu rumah tapi belum bekerja. Hasil tabel 3 menunjukan kategori tanggungan keluarga yang paling banyak berada pada tanggungan keluarga 4-5 orang. Kategori tersebut dapat diartikan pemilik tanggungan keluarga kategori sedang dan dapat disimpulkan bahwa kesejahteraan keluarga tersebut dapat dikatan sejahtera karna pengeluaran akan terkontrol dan tidak terlalu berlebihan dalam pengeleruaran kebutuhan keluarga. Badan Pusat Statistik, (2000) telah membagi kategori menjadi 3 golongan dalam pengelompokkan tanggungan keluarga, yaitu 1-3 orang merupakan kategori kecil, 4-5 orang merupakan kategori sedang dan $>7$ orang merupakan kategori besar.

\subsection{Responden Berdasarkan Lamanya Kerja}

Tabel 4. Karakter Responden Berdasarkan Lamanya Kerja

\begin{tabular}{lll} 
Lamanya Kerja & Frekuensi & Presentase (\%) \\
\hline 5 - 15 Tahun & 20 & $62.5 \%$ \\
16 - 25 Tahun & 11 & $34.375 \%$ \\
>26 Tahun & 1 & $3.125 \%$ \\
\hline Total & 32 & $100 \%$ \\
\hline
\end{tabular}

Sumber : Data Primer Diolah, 2019

Tabel 4 menunjukan data pedagang melon yang telah bekerja sebagai pedagang 5 15 tahun sebanyak 20 orang $(62,5 \%)$, sedangkan pedagang $16-25$ tahun sebanyak 11 orang $(34,37 \%)$ dan pedagang $>26$ tahun sebanyak 1 pedagang $(3,12 \%)$. Jumlah pedagang melon terbanyak dari pedagang Pasar Induk Osowilangun Surabaya (PIOS) merupakan pedagang yang telah berdagang selama 5 - 15 tahun. Wahyono, (2017) mengungkapkan bahwa lamanya kerja sebuah pedagang tidak menimbulkan pengalaman berusaha, dimana pengalaman dapat mempengaruhi pengamatan seseorang dalam bertingkah laku. Semakin lama seseorang menekuni bidang usaha maka seseorang tersebut akan mempengaruhi produktivitasnya (kemampuan profesionalnya atau keahliannya), sehingga dapat menambah efisiensi dan mampu menekan biaya produksi lebih kecil daripada hasil penjualan.

\section{Uji Asumsi Klasik}

Sebelum peneliti melakukan analisis regresi linier berganda maka terlebih dahulu dilakukan uji asumsi klasik untuk mengetahui ada atau tidaknya penyimpangan terhadap asumsi klasik. Uji asumsi klasik meliputi uji normalitas, uji multikolieraritas dan uji heteroskedastisitas.

\subsection{Uji Normalitas}

Uji normalitas bertujuan untuk menguji apakah dalam model regresi, variable pengganggu atau residual memiliki distribusi normal. Model regresi yang baik adalah distribusi normal atau mendekati normal. Jika data menyebar di sekitar garis diagonal dan mengikuti arah garis diagonal atau grafik histogramnya menunjukkan pola distribusi normal, maka model regresi memenuhi asumsi 
ISSN : 2622-6154 (print)

normalitas, dan sebaliknya maka model regresi tidak memenuhi asumsi normalitas (Ghozali, 2006).

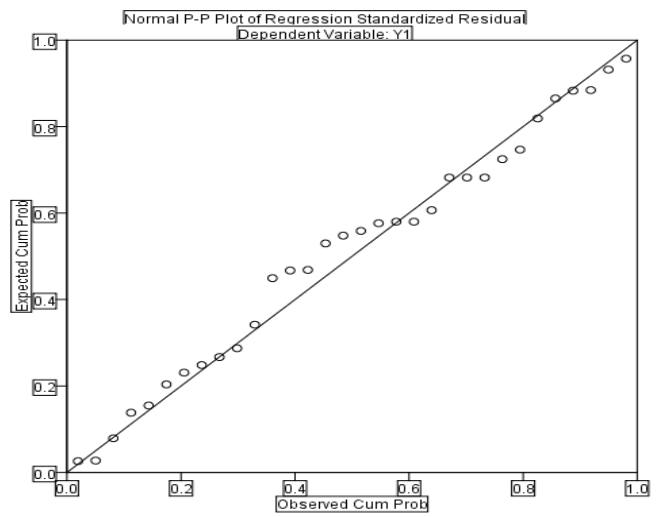

Gambar 1. Uji Normalitas

Berdasarkan gambar di atas menjunjukan bahwa titik-titik pada gambar menyebar disekitar garis diagonal, maka dapat disimpulkan bahwa model regresi layak dipakai atau telah memenuhi asumsi normalitas dengan melihat titik-titik pada gambar 5.5.1 berada disekitar garis dan mengikuti arah garis diagonal.

\subsection{Uji Multikolinearitas}

Uji multikolinearitas digunakan untuk mengetahui ada atau tidak nya variabel independen yang memiliki kemiripan dengan variabel independen dalam satu model regresi, jika terdapat korelasi maka dikatakan bahwa model regresi mengalami masalah multikolonearitas. Uji muitikolinearitas dilakukan dengan cara melihat nilai toletansi dan Variance Inflation Factor (VIF).

Berdasarkan table output koefisient pada bagian Collinearity Statistics diketahui nilai tolerance variable $\mathrm{X} 1=0,368, \mathrm{X} 2=0,344, \mathrm{X} 3=0,685$ dan $\mathrm{X} 4=0,610$. Sementara nilai VIF variable $\mathrm{X} 1=2,717, \mathrm{X} 2=2,903, \mathrm{X} 3=1,460$ dan $\mathrm{X} 4=1,638$. Mengacu pada syarat diatas, hasil output nilai tolerance $\mathrm{X} 1, \mathrm{X} 2, \mathrm{X} 3$ dan X4 memiliki nilai $>0,1$. Hasil otput nilai VIF X1, X2, X3, X4 memiliki nilai <10. Kesimpulannya adalah tidak terjadi korelasi diantara variable bebas karena nilai toleran dan VIF telah memenuhi syarat dari ketetapan yang telah ditentukan, yaitu nilai tolerance diatas 0,1 dan nilai VIF dibawah 10

\subsection{Uji Heterokedastisitas}

Mendeteksi ada tidaknya heteroskedastisitas pada suatu model dapat dilihat dari pola gambar scatterplot model tersebut. Dasar analisi uji heterokedeksitas menurut Ghozali, (2006) yaitu jika ada pola tertentu yang teratur maka telah terjadi heterokedeksitas, sedangkan medel regresi yang baik merupakan Homokedastisitas atau tidak heterokededastisitas. Berikut merupakan gambar hasil dari ujiheterokedastisitas: 


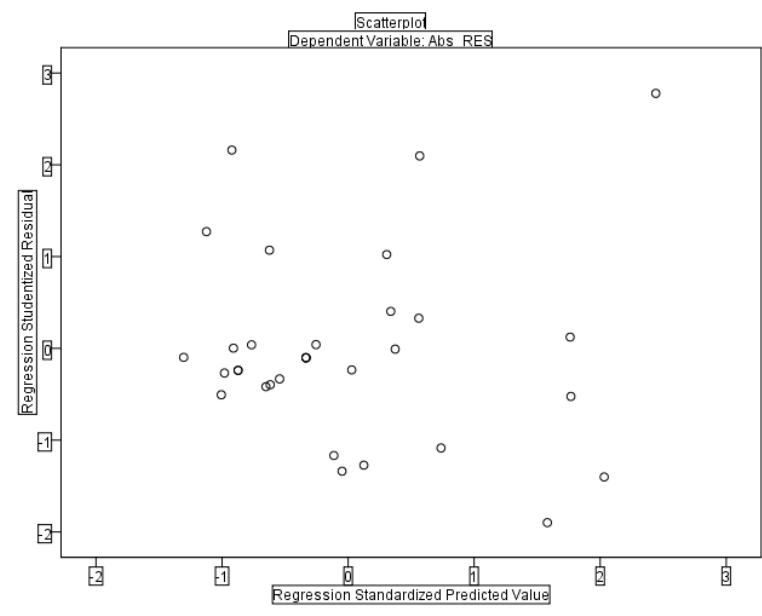

Gambar 2. Uji Heterokedastisitas

Gambar 4 menunjukan penyebaran titik-titik tidak berpola dan berada diatas atau dibawah angka 0 pada sumbu $\mathrm{Y}$ dan dapat disimpulkan bahwa tidak terjadi heterokedastisitas atau terjadi homokedastisitas yang berarti varian dari residual satu pengamatan ke pengamatan lain tetap.

\section{Uji $\mathbf{R}^{2}$ (Koefisien Determinasi)}

Hasil uji R2 digunakan untuk mengetahui persentase pengaruh semua variabel independen yaitu harga melon, biaya transportasi dan biaya pemeliharaan terhadap variabel dependen pengadaan melon. Berdasarkan hasil analisis $\mathrm{R}^{2}$ diperoleh 0,777 , yang berarti presentase harga melon, biaya transportasi dan biaya pemeliharaan terhadap pengadaan sebesar $77,7 \%$ dan sisanya sebesar $22,3 \%$ dipengaruhi oleh variabel lain yang tidak diteliti.

\section{Uji Simultan}

Uji $\mathrm{F}$ digunakan untuk mengetahui pengaruh variable bebas secara bersama-sama terhadap variable terikat. Nilai Fhitung dapat diperoleh dari hasil analisi regresi. Berdasarkan perhitungan dari hasil analisis regresi dapat diketahui bahwa nilai $\mathrm{F}$ hitung sebesar 23.541 dan sig.F sebesar 0,000. Muhammad Yusuf, (2011) mengemukakan bahwa Ho diterima jika nilai $\mathrm{F}$ table $>\mathrm{F}$ hitung atau nilai sig $\mathrm{F}>$ alpha. Jadi, pada penelitian ini $\mathrm{F}$ tabel $<\mathrm{F}$ hitung $(2,71<23.541)$ dan sig.F $<$ alpha $(0,000<0,05)$. Maka diduga terdapat pengaruh harga beli melon, harga jual melon, biaya transportasi melon dan biaya pemeliharaan melon terhadap pengadaan melon secara bersama-sama.

\section{Uji Parsial}

Mengetahui variable mana yang paling berpengaruh terhadap variable terikat menggunakan uji t. Jika suatu koefisien regresi signifikan menunjukkan seberapa jauh pengaruh satu variabel penjelas atau independen secara individual dalam menerangkan variasi variabel dependen atau terikat. Pengujian ini dilakukan dengan menggunakan cara membandingkan $t$ hitung dan $t$ tabel, dengan tingkat signifikansi $t<0,05(5 \%)$. Jika $\mathrm{t}$ hitung $>\mathrm{t}$ tabel tabel maka secara individual variabel bebas atau independen 
berpengaruh signifikan terhadap variabel terikat atau dependen. Hipotesis yang digunakan yaitu $\mathrm{Ho}=$ diduga tidak terdapat pengaruh harga beli melon terhadap pengadaan melon.

a) Harga beli (X1)

Hasil pengujian dengan SPSS diperoleh untuk variabel X1 diperoleh nilai t hitung = 1.833. Hasil nilai $t$ tabel sebesar 2,052, dimana $t$ hitung $<\mathrm{t}$ tabel. Nilai signifikansi 0,078, dimana nilai signifikansi tersebut lebih besar dari taraf $0,05(\alpha)$ yang berarti Ho diterima dan $\mathrm{H} 1$ ditolak. Artinya tidak terdapat pengaruh harga beli melon terhadap pengadaan melon.

b) Harga Jual ( X2)

Hasil pengujian dengan SPSS diperoleh untuk variabel X2 diperoleh nilai t hitung = 1.265. Hasil nilai $t$ tabel sebesar 2,052, dimana $t$ hitung $<t$ tabel. Nilai signifikansi 0,217, dimana nilai signifikansi tersebut lebih besar dari taraf $0,05(\alpha)$ yang berarti Ho diterima dan H1 ditolak. Artinya tidak terdapat pengaruh harga jual melon terhadap pengadaan melon.

c) Biaya transportasi ( X3)

Hasil pengujian dengan SPSS diperoleh untuk variabel X3 diperoleh nilai t hitung = 5.310. Hasil nilai $t$ tabel sebesar 2,052, dimana $t$ hitung $>t$ tabel. Nilai signifikansi 0,000, dimana nilai signifikansi tersebut lebih kecil dari taraf $0,05(\alpha)$, yang berarti Ho ditolak dan $\mathrm{H} 1$ diterima. Artinya terdapat pengaruh biaya transportasi melon terhadap pengadaan melon.

d) Biaya pemeliharaan melon ( X4)

Hasil pengujian dengan SPSS diperoleh untuk variabel X4 diperoleh nilai t hitung = 3.517. Hasil nilai t tabel sebesar 2,052, dimana t hitung $>t$ tabel. Nilai signifikansi 0,002 , dimana nilai signifikansi tersebut lebih kecil dari taraf $0,05(\alpha)$ yang berarti Ho ditolak dan $\mathrm{H} 1$ diterima. Artinya terdapat pengaruh biaya pemeliharaan melon terhadap pengadaan melon.

\section{Regresi Linier}

Mengananlisi tentang hubungan antara variable pengadaan melon dengan variable harga beli melon, harga jual melon, biaya transportasi dan biaya pemeliharaan . hubuyngan variable dependen dengan indepen ditunjukan pada persamaan berikut:

$$
\mathrm{Y}=14867.283+0,628 \mathrm{X} 1+(-0,333) \mathrm{X} 2+(-13.423) \mathrm{X} 3+(-78.908) \mathrm{X} 4
$$

Nilai konstanta sebesar 14867.283 artinya jika variabel bernilai konstan, maka nilai Y memiliki nilai 14867.283. Berdasarkan hasil analisis dan pengujian hipotesis pengaruh harga beli melon terhadap pengadaan melon di Pasar Indik Osowilangun Surabaya pengujian hipotesis dengan melalui uji t diperoleh nilai t hitung sebesar 1.833 sedangkan nilai t tabel sebesar 2,05 dengan nilai signifikansi sebesar 0,078 dimana nilai tersebut lebih besar disbanding nilai $\alpha(0,05)$. Sehingga dapat disimpulkan bahwa variabel harga beli melon (X1) tidak berpengaruh terhadapan pengadaan melon, dikarenakan pedagang akan tetap melakukan pengadaan walaupun harga melon rendah atau tinggi untuk memenuhi kebutuhan pasar. Hasil penelitian tersebut sejalan dengan Indrawati, (2013) yang mengatakan bahwa harga pembelian pedagang dibagi atas tiga keadaan yaitu pada saat pasokan barang normal, sedikit dan banyak, sehingga tidak mempengaruhi pedagang melakukan kegiatan pengadaan, yang berpengaruh yaitu 
banyaknya jumlah pengadaan pedagang dikala kondisi tertentu. Wibowo \& Adp, (2017) juga mengemukakan didalam penelitan terdahulu, bahwa hasil panenan petani sebagian besar masih langsung diambil oleh distributor buah yang nanti akan dikirim kepada pedagang buah besar. Struktur yang masih sederhana dikarekan para petani melon belom cukup memiliki system kelembagaan pertanian yang mnapan, sehingga hasil dari pertanian akan tetap berpusat pada pedagang besar.

Berdasarkan hasil analisis dan pengujian hipotesis pengaruh harga jual melon terhadap pengadaan melon di Pasar Indik Osowilangun Surabaya pengujian hipotesis dengan melalui uji $\mathrm{t}$ diperoleh nilai $\mathrm{t}$ hitung sebesar $-1,265$ sedangkan nilai $\mathrm{t}$ tabel sebesar 2,052 dengan nilai signifikansi sebesar 0,217 dimana nilai tersebut lebih besar disbanding nilai $\alpha(0,05)$. Sehingga dapat disimpulkan bahwa variabel harga jual melon (X2) tidak berpengaruh terhadapan pengadaan melon. Indrawati, (2013) mengemukakan penentuan harga jual dilihat dari 3 faktor yaitu kondisi pasokan normal, banyak dan sedikit. Sehingga dalam proses pengadaan barang untuk pedagang bukan dipengarui oleh harga jual akan tetapi jumlah barang yang diadakan yang memiliki pengaruh.

Berdasarkan hasil analisis dan pengujian hipotesis pengaruh biaya transportasi melon (X3) terhadap pengadaan melon di Pasar Indik Osowilangun Surabaya pengujian hipotesis dengan melalui uji $\mathrm{t}$ diperoleh nilai $\mathrm{t}$ hitung sebesar $-5,310$ sedangkan nilai $\mathrm{t}$ tabel sebesar 2,052 dengan nilai signifikansi sebesar 0,000 dimana nilai tersebut lebih kecil dibanding nilai $\alpha(0,05)$, Sehingga dapat disimpulkan bahwa variabel biaya transportasi melon (X3) berpengaruh terhadapan pengadaan melon. Adapun besarnya pengaruh sebesar $\beta 3=-13,423$. Jika variabel biaya transportasi melon (X3) bertambah sebesar Rp. 1/kg, berarti pengadaan melon (Y) akan menurun sebesar 13,423. Sebaliknya,jika biaya transportasi melon (X3) berkurang, maka pengadaan melon akan bertambah. Pranati, Jaya, \& Sahari, (2018) mengemukakan setiap perusahaan akan mengalami masalah dalam hal pendistribusian barang, untuk itu perusahaan harus mampu mengatur biaya transportasi yang digunakan untuk pendistribusian barang tersebut agar tetap terjadi rentang antara pengeluaran dan pemasukan perusahaan. Sejalan dengan hal tersebut, perusahaan memerlukan rencana pendistribusian produk yang tepat agar terhindar dari kurang optimalnya pemasaran yang akan berdampak pada kerugian.

Berdasarkan hasil analisis dan pengujian hipotesis pengaruh biaya pemeliharaan melon (X4) terhadap pengadaan melon di Pasar Indik Osowilangun Surabaya pengujian hipotesis dengan melalui uji $t$ diperoleh nilai t hitung sebesar $-3,517$ sedangkan nilai $t$ tabel sebesar 2,052 dengan nilai signifikansi sebesar 0,002 dimana nilai tersebut lebih kecil dibanding nilai $\alpha(0,05)$, Sehingga dapat disimpulkan bahwa variabel biaya pemeliharaan melon (X4) berpengaruh terhadapan pengadaan melon. Adapun besarnya pengaruh sebesar $\beta 4=-78,908$. Jika variabel biaya pemeliharaan melon (X4) bertambah sebesar Rp. 1/kg, berarti pengadaan melon (Y) akan menurun sebesar 13,423. Sebaliknya,jika biaya pemeliharaan melon (X4) berkurang, maka pengadaan melon akan bertambah. Pemeliharaan atau perawatan merupakan kegiatan yang bertujuan agar produk atau buah melon dapat tetap terjaga kualitasnya dan juga sebagai menentuan atau pemisah harga melon berdasarkan grade melon tersebut. Penentuan grade atau sortasi merupakan kegiatan yang bertujuan untuk memisahkan produk yang baik dengan yang kurang baik atau bahkan buruk (A. Zubaidi, 2012).

Kesimpulan dari analisis diatas menyatakan bahwa variabel yang memiliki pengaruh yang besar yaitu pada variabel biaya transportasi (X3) dan variabel biaya pemeliharaan (X4). 
ISSN : 2622-6154 (print)

\section{Resiko}

Beberapa tipe kerjasama yang dilakukan antar pengirim dan pedagang, antara lain yaitu dengan nota, nota yang dimaksud yaitu pengirim memberikanhasil dari tinase pembelian dengan keterang grade $\mathrm{A}, \mathrm{B}$ dan $\mathrm{C}$ yang sudah jelas. Hal tersebut berarti pengirim ingin pedagang membayar sesuai apa yang tertera dengan harga yang telah disepakati sehingga pengirim tidak mau tau tentang untung atau rugi yang diperoleh pedagang. Hal tersebut rentan terjadinya perselisihan dan resiko hanya sesekali kerjasama dan tidak berkelanjutan. Masalah yang dihadapi antara lain dengan system sepertiini yaitu, kualitas barang yang tidak sesuai pedagang inginkan, tonase yang kurang sesuai antara grade yang telah ditulis nota dengan yang dipilah oleh pihak pasar, beban resiko yang dimiliki oleh pedagang lebih besar.

Kerjasama dengan system yang lainnya yaitu komisi, komisi yang diartikan yaitu pedagang hanya menjual barang dari pengirim. Keuntungan yang diperoleh pedagang yaitu dari presentase dari hasil penjualan seluruh barang yang dikirim. Presentase tersebut di pasar induk osowilangun Surabaya memiliki kesamaan semua pedagang yaitu $7 \%$ dari hasil seluruh penjualan. System seperti ini akan sangat menguntungkan pedagang yang tidak sama sekali menanggung beban kerugian. Kerugian akan terbebankan kepada pengirim, karna pedagang hanya bertugas sebagai penjual yang tidak tahu berapa nota pembelian pengirim dan hanya berjualan dengan harga pasaran yang ada dengan kualitas barang yang ada. Kelemahan system seperti ini yaitu perang harga antara pedagang yang menyebabkan harga melon tidak stabil dikarekan pedagang dengan system seperti ini hanya berfikir bagaimana dagangan mereka habis dan tidak melihat dari aspek untung atau rugi karna hal tersebut dibebankan kepada pengirim.

Kerjasama yang terakir yaitu pedagang dan pengirim memiliki saham di lapak tersebut. Maksudnya hal ini yaitu kerjasama 2 orang untuk memiliki lapak yang sama dan dengan pembagian tugas. Pembagian tugas pertama yaitu dibagian lapak atau sebagai penjual saja dan yang satunya bagian lapang mencari barang sendiri dari petani. System ini banyak memiliki keuntungan antara lain satu dengan yang lain memiliki tanggung jawab atas keuntungan atau kerugian yang mereka alami, koneksi yang akan lebih luas sehingga dapat memprediksi pola harga dari bebagai wilayah, harga yang mreka tentukan akan lebih bersaing dari yang lainnya.

\section{KESIMPULAN}

Faktor-faktor yang mempengarui pengadaan melon di Pasar Induk Osowilangun Surabaya dengan harga jual, harga beli, biaya transportasi dan biaya perawatan terhadap pengadaan melon. Harga jual dan beli melon bukan merupakan faktor utama yang mempengaruhi pengadaan melon, dikarekan bahwa pedagang akan tetap melakukan pengadaan dengan harga beli dan harga jual berapapun untuk mengisi kebutuhan mereka. Faktor utama yang mempengaruhi pengadaan melon yaitu biaya transportasi dan biaya pemeliharaan dikarekan karna biaya transportasi dan pemeliharaan yang tidak sesuai atau terlalu tinggi mengakibatkan kerugian bagi pedagang. Pedagang tidak dapat menutup kerugian hanya dengan meningkatkan harga jual dengan alasan faktor persaingan harga antar sesama pedagang. Resiko atau kendala melakukan pengadaan antara lain tentang supliyer yang dimiliki pedagang di Area Jawa Timur,biaya 
ISSN : 2622-6154 (print)

transportasi yang lebih ringan,kualitas melon yang dapat dipantau, harga yang tidak berbeda jauh dengan di luar Jawa Timur, resiko pengiriman, persaingan harga.

\section{DAFTAR PUSTAKA}

A. Zubaidi, A. A. S. (2012). Analisis Efisiensi Usahatani Dan Pemasaran Melon Di Kecamatan Muncar Kabupaten Banyuwangi. 12(2), 19-26.

BPS. (2014). Statiistiik Produksii Hortiikultura Tahun 2014. jakarta: Diirrekttorratt Jenderrall Horrttiikulltturra,, Kementterriian Perrttaniian.

Ghozali, I. (2006). Analisis Multivariate dengan Program SPSS. Badan Penerbit Universitas Diponegoro. Semarang., 2(1), 1-21.

Pranati, N. M. A., Jaya, A. I., \& Sahari, A. (2018). Menggunakan Model Transportasi Metode Stepping. 15(September 2016), 48-57.

Purwanto, A., \& Taftazani, B. M. (2018). Pengaruh Jumlah Tanggungan Terhadap Tingkat Kesejahteraan Ekonomi Keluarga Pekerja K31 Universitas. Jurnal Pekerjaan Sosial, 1, 33-43.

Rismawati, S. D. (2010). Pedagang Pasar Tiban Dan Modal Sosial Membangun Tatanan Sosial-Ekonomi Lokal. Jurnal Penelitian, 7(9), 1-14.

Simatupang, J. T. (2004). Pencurahan Tenaga Kerja Pada Usahatani Melon. JURNAL PENELITIAN BIDANG ILMU PERTANIAN, 3(2), 9-13.

Toti, I. (2013). Analisis Perilaku Pedagang Dalam Pembentukkan Harga Barang Kebutuhan Pokok Di Kota Pekanbaru. Jurnal Ekonomi, 21, 1-9.

Wahyono, B. (2017). Analisis Faktor-Faktor Yang Mempengaruhi Pendapatan Pedagang Di Pasar Bantul Kabupaten Bantul. Jurnal Pendidikan Dan Ekonomi, 6(4), 388-399.

Wibowo, T. J., \& Adp, G. (2017). Strategi Peningkatan Kinerja Rantai Pasok Agrobisnis Melon Apollo Di Kota Cilegon. (November), 1-2.

Yusuf, M., \& Ramadhani, Y. (2011). Analisis efisiensi, skala dan elastisitas produksi dengan pendekatan cobb-douglas dan regresi berganda. 4, 61-68. 